\title{
The genus Nipponaetes (Hymenoptera: Ichneumonidae: Cryptinae) in Costa Rica, with a reassessment of the generic limits
}

\author{
GAVIN R. BROAD ${ }^{1,4}$, Nina M. LAURENNE² and DonALD L.J. QUICKE ${ }^{3,4}$ \\ ${ }^{1}$ Centre for Ecology and Hydrology, Monks Wood, Abbots Ripton, Huntingdon PE28 2LS, UK; e-mail: gabro@ceh.ac.uk \\ ${ }^{2}$ Finnish Museum of Natural History, Zoological Museum, Entomological Division, P.O. Box 17 (P. Rautatiekatu 13), \\ FIN-00014 University of Helsinki, Finland; e-mail: nina.laurenne@ helsinki.fi \\ ${ }^{3}$ Department of Biological Sciences, Imperial College London, Silwood Park Campus, Ascot, Berks. SL5 7PY, UK; \\ e-mail: d.quicke@imperial.ac.uk \\ ${ }^{4}$ Department of Entomology, The Natural History Museum, Cromwell Road, London SW7 5BD, UK
}

Keywords. Ichneumonidae, Cryptinae, Tryphoninae, Nipponaetes, Zurquilla, 28S, host, spider, phylogeny, new synonymy

\begin{abstract}
The endemic Costa Rican genus Zurquilla Gauld, 1997, is transferred from the ichneumonid subfamily Tryphoninae (tribe Oedemopsini) to the Cryptinae (tribe Phygadeuontini) and synonymised with Nipponaetes Uchida, 1933. This decision is justified using morphological and molecular (28S D2-3 ribosomal DNA sequence) evidence. We briefly discuss the phylogenetic utility of characters that led to the type species of Zurquilla being described as a tryphonine and provide a host record that indicates that Nipponaetes is a parasitoid of spider egg sacs.
\end{abstract}

\section{INTRODUCTION}

Amongst the Hymenoptera material collected by DLJQ and NML on a trip to Thailand in May 2001 was an unfamiliar female phygadeuontine (Cryptinae: Phygadeuontini). The specimen was identified as Nipponaetes haeussleri (Uchida, 1933), Nipponaetes being a small genus of the old world tropics placed by Townes (1970) in his subtribe Rothneyiina of the tribe Phygadeuontini. Whilst we were identifying the specimen, recollection of the description of the tryphonine genus Zurquilla Gauld, 1997 , indicated that this genus might be synonymous with Nipponaetes. Examination of type material of the type species of the genus, Z. hansoni Gauld, 1997, in The Natural History Museum (London) has leant support to this hypothesis. Here we justify the reclassification and synonymy of the genus Zurquilla and present limited host information based on specimens in The Natural History Museum (London). The genus Nipponaetes, represented by the species $N$. haeussleri, is also recorded from Thailand for the first time.

To establish the taxonomic position of the Thai specimen of $N$. haeussleri, and as part of ongoing projects investigating the higher-level phylogeny of the Ichneumonidae and of the Cryptinae in particular (Belshaw et al., 1998; Quicke et al., 2000; Laurenne et al., 2002), a 28S D2-3 ribosomal DNA sequence was obtained from this specimen. An estimate of relationships was derived from phylogenetic analysis of a set of sequences from 30 ichneumonids of the subfamilies Cryptinae, Ichneumoninae, Tryphoninae, Brachycyrtinae, Banchinae, Neorhacodinae, Ctenopelmatinae, Orthocentrinae, Orthopelmatinae and Xoridinae. As we consider the species of Nipponaetes and Zurquilla to represent the same genus (see Discussion) there are two alternative hypotheses: (1) that the genus Zurquilla was mistakenly described in the Tryphoninae and in fact belongs in the Cryptinae, or (2) Nipponaetes is an aberrant tryphonine and does not belong in the Cryptinae. By sequencing a taxonomically wide-ranging selection of cryptines and tryphonines we are able to refute the second of these hypotheses.

\section{MATERIAL AND METHODS}

\section{Specimens}

The taxa used in our phylogenetic analyses were chosen to represent, as far as specimen availability would allow, the tribes of cryptines and tryphonines, together with outgroups. All three genera of the Rothneyia group were sequenced, as were two oedemopsine genera and representatives of seven of the eight tribes of Tryphoninae (no material of the Ankylophonini was available). Table 1 details the provenance and European Molecular Biology Institute nucleotide sequence database (EMBL) accession numbers of ichneumonids used for DNA extraction. All molecular vouchers will be deposited in The Natural History Museum (London) (BMNH) except for the specimen of Hyperacmus crassicornis (Gravenhorst, 1829), which is deposited in the National Museums of Scotland (Edinburgh). Identifications were carried out by GRB, corroborated using the collections of the The Natural History Museum and American Entomological Institute (Gainesville) (AEI). Although type material of $N$. haeussleri was not examined, we are confident of the identification judging by the original description (Uchida, 1933) and the specific characters given by Momoi (1970). The taxa used in the analyses are a subset of the taxa being sequenced as a more wide-ranging analysis of ichneumonid and, particularly, cryptine relationships (Laurenne et al. in preparation).

Of the Rothneyia group of cryptines (= Rothneyiina Townes, 1970), we were able to examine the morphology of four female specimens of $N$. haeussleri (one light-trapped in Thailand, three reared from spider egg sac(s) in India, in the BMNH as detailed below); one female specimen of $N$. inelegans (Seyrig, 1952) 
TABLE 1. Taxa included in study, provenance of specimens and EMBL accessions numbers for D2-3 28S rDNA sequences.

\begin{tabular}{|c|c|c|c|}
\hline $\begin{array}{c}\text { Subfamily } \\
\text { Tribe }\end{array}$ & Species & Provenance & EMBL accession number \\
\hline \multicolumn{4}{|l|}{ Cryptinae } \\
\hline \multirow[t]{8}{*}{ Phygadeuontini } & Nipponaetes haeussleri (Uchida, 1933) & Thailand & AF423138 \\
\hline & Hyparcha sp. & Malaysia: Cameron Highlands & AY389165 \\
\hline & Rothneyia sp. & Malaysia: Cameron Highlands & AY222795 \\
\hline & Chirotica sp. & Belize & AF423157 \\
\hline & Paraphylax sp. & no data & AJ302867 \\
\hline & Bentyra sp. & Malaysia & AF423165 \\
\hline & Palpostilpnus sp. & Malaysia: Sabah & AF423137 \\
\hline & Stilpnus pavoniae (Scopoli, 1763) & England: Silwood Park & AY222805 \\
\hline Hemigasterini & Cubocephalus anatorius (Gravenhorst, 1829) & England: Hilbre Island & AY222801 \\
\hline \multirow[t]{3}{*}{ Cryptini } & Buathra laborator (Thunberg, 1822) & Turkey & AY222800 \\
\hline & Microstenus canaliculatus Szépligeti, 1916 & Malaysia: Cameron Highlands & AY222802 \\
\hline & Nematopodius debilis (Ratzeburg, 1852) & England: Silwood Park & Z97921 \\
\hline \multicolumn{4}{|l|}{ Ichneumoninae } \\
\hline \multirow[t]{2}{*}{ Alomyini } & Alomya semiflava Stephens, 1835 & England: Silwood Park & AY222808 \\
\hline & Misetus oculatus (Wesmael, 1845) & England: Silwood Park & AF418559 \\
\hline Ichneumonini & Amblyteles armatorius (Forster, 1771) & England: Silwood Park & AY222803 \\
\hline \multicolumn{4}{|l|}{ Tryphoninae } \\
\hline \multirow[t]{2}{*}{ Oedemopsini } & Oedemopsis ryitoi Gauld, 1997 & Costa Rica & AY222807 \\
\hline & Thymaris sp. & Malaysia: Sabah & AY222809 \\
\hline Eclytini & Eclytus exornatus (Gravenhorst, 1829) & Finland: Värriö & AY222797 \\
\hline Sphinctini & Sphinctus gastoni Gauld, 1997 & Costa Rica & AY389166 \\
\hline Phytodietini & Netelia (Monomacrodon) bicolor (Cushman, 1934) & Burma & AY222806 \\
\hline Idiogrammatini & Idiogramma sp. & Caucasus & AY389167 \\
\hline Tryphonini & Tryphon rutilator (Linnaeus, 1761) & Turkey & AY389168 \\
\hline Exenterini & Excavarus sibiricola Kasparyan, 1990 & Russia: Primorje & AY389164 \\
\hline Brachycyrtinae & Brachycyrtus sp. & no data & Y18585 \\
\hline Ctenopelmatinae & Euryproctus sp. & Germany: Bayerische Wald & AY222798 \\
\hline Neorhacodinae & Neorhacodes enslini (Ruschka, 1922) & England: Chippenham Fen & Z97910 \\
\hline Banchinae & Sjostedtiella sp. & Togo & AY222796 \\
\hline Orthopelmatinae & Orthopelma sp. & Turkey: Bolu Bolu & AY222799 \\
\hline Orthocentrinae & Hyperacmus crassicornis (Gravenhorst, 1829) & Scotland: Wester Ross & AY222804 \\
\hline Xoridinae & Odontocolon dentipes (Gmelin, 1790) & England: Silwood Park & AJ302924 \\
\hline
\end{tabular}

from Madagascar in the AEI; six undescribed species of Nipponaetes in the collections of the AEI; the female holotype and male paratype of Zurquilla hansoni; an undescribed species of Hyparcha Townes, 1970 (Malaise-trapped in the Cameron Highlands, Malaysia); and three described species of Rothneyia Cameron, 1897, from South East Asia in the BMNH, together with two unnamed specimens Malaise-trapped in the Cameron Highlands, Malaysia.

\section{Laboratory protocols}

A hind leg of each insect sample was homogenised in $100 \mu \mathrm{l}$ TE-buffer ( $1 \mathrm{M}$ Tris, $5 \mathrm{M} \mathrm{NaCl}, 0.5 \mathrm{M}$ EDTA), incubated in $37^{\circ} \mathrm{C}$ overnight with proteinase $\mathrm{K}$, which was followed by sodium acetate/ethanol precipitation and re-suspension in $50 \mu 1 \mathrm{TE}$ buffer. The PCR conditions were 30 cycles of $98^{\circ} \mathrm{C}$ denaturation $(15 \mathrm{~s}), 50^{\circ} \mathrm{C}$ annealing $(30 \mathrm{~s})$ and $72^{\circ} \mathrm{C}$ extension $(40 \mathrm{~s})$ with an initial denaturation of $3 \mathrm{~min}$ at $93^{\circ} \mathrm{C}$ and a final extension of 3 min. The D2-3 region of the $28 \mathrm{~S}$ rDNA gene was amplified using the following primers: forward 5'-AGA GAG AGA GTT

\section{CAA GAG TAC GTG-3', reverse 5'-TAG TTC ACC ATC TTT} CGG GTC-3'.

\section{Phylogenetic analysis}

The phylogenetic reconstruction was carried out using the program POY that optimizes characters straight to the tree without a priori alignment (Wheeler \& Gladstein, 2000). The data set was split into 18 blocks to speed up the analysis and these blocks were anchored in conserved regions where there was no length variation. The xoridine Odontocolon dentipes (Gmelin, 1790) was specified as the outgroup because the Xoridinae have consistently appeared as basal to the Tryphoninae and Cryptinae in molecular analyses (Belshaw et al., 1998; Belshaw \& Quicke, 2002). The POY command line used was the following: norandomizeoutgroup, noleading, random 50, multibuild 6 , treefuse, fuselimit 50 , slop 5 , checkslop 3 , buildmaxtrees 2 , maxtrees 2 , holdmaxtrees 50 , driftspr, drifttbr, numdriftspr 5, numdrifttbr 5, fitchtrees, seed -1 . 
TABLE 2. Summary of results of phylogenetic analyses of relationships of Nipponaetes from 28S rDNA sequence alignments under different gap: substitution parameters.

\begin{tabular}{cccc}
\hline Gap:substitution ratio & Tree length & Number of most parsimonious trees & Sistergroup of Nipponaetes \\
\hline $1.5: 1$ & 1756 & 4 & Brachycyrtus/Hyperacmus \\
$1.75: 1$ & 3636 & 1 & Hyparcha \\
$1.8: 1$ & 4574 & 1 & Hyparcha \\
$2.0: 1^{*}$ & 945 & 21 & Rothneyia \\
$2.0: 1^{*}$ & 945 & 9 & Hyparcha \\
$2.5: 1$ & 2006 & 7 & Hyparcha \\
$3.0: 1$ & 1060 & 8 & Hyparcha \\
\hline
\end{tabular}

*two islands of most parsimonious trees were recovered from analysis with the gap:substitution cost ratio set at 2.0:1

The data were analysed with gap:substitution ratios set at $1.5: 1,1.75: 1,1.8: 1,2: 1,2.5: 1$ and $3: 1$ in order to explore the sensitivity of the results to alignment parameters. POY searches were run on a cluster at the Centre of Scientific Computing (University of Helsinki) using 8 processors of a 128 processor (type R12000, based on S2MP acrhitecture) set-up.

\section{RESULTS}

Fig. 1 shows the strict consensus trees resulting from analyses with each of the six gap:substitution ratios. Nipponaetes haeussleri groups with the Cryptinae + Ichneumoninae in all analyses except that with the very low gap:substitution cost ratio 1.5:1. With the majority of gap:substitution costs, it emerges as the sister taxon to the rothneyiine genus Hyparcha (Table 2), though with the 2:1 analysis two islands of optimal trees were found and in one of these Nipponaetes grouped with the other rothneyiine genus, Rothneyia. The representative oedemopsine genera, Oedemopsis Tschek, 1869, and Thymaris Förster, 1869, group with the other tryphonine genera. Thus we reject the hypothesis that Nipponaetes (including Zurquilla) is a tryphonine.

\section{DISCUSSION}

The presence of a complete sternaulus and fused first metasomal tergite and sternite, with the spiracles placed well behind the middle of the segment, support the molecular evidence that Nipponaetes is a cryptine. It can be classified in the tribe Phygadeuontini based on the complete propodeal carination and the form of the sternaulus (ending above the lower hind corner of the mesopleuron). Comparison of specimens of $N$. haeussleri with the holotype female and a paratype male of Zurquilla hansoni (BMNH) leads us to believe that these two species are congeneric. Within the Oedemopsini (Tryphoninae), apomorphies of Zurquilla are, according to Gauld (1997), a single bulla in vein $2 m-c u$ of the forewing and the presence of a more or less complete posterior transverse carina on the mesosternum. Both of these features are found in the rothneyiine genera and some chiroticine genera of the Phygadeuontini. Gauld (1997) also listed four features that indicated an oedemopsine affinity for $Z$. hansoni: (1) clypeus with a subapical fringe of stout hairs; (2) the characteristic mandible, with the upper tooth about four times the length of the lower; (3) the un-notched ovipositor; and (4) the long, deeply impressed and posteriorly convergent notauli. The form of the clypeus would be the most convincing tryphonine feature but the fringe of setae is not of the regularly spaced, dense form found in typical oedemopsine genera. In fact, all of these features are found separately or in combination in the rothneyiine and various chiroticine genera, although only with Nipponaetes displaying such a disparity in mandibular tooth size (Townes, 1970; Gauld, 1984; examination of specimens in BMNH). Zurquilla lacks such oedemopsine features as the membranous area on the lower valve of the ovipositor, a synapomorphy of the tribe in Gupta's (1988) phylogeny, and the presence of glymmae on the first tergite, a presumably plesiomorphic character found in most tryphonines. Zurquilla hansoni is mostly pale in coloration, including the head, which is a fairly unusual colour pattern for the Phygadeuontini. However, several species of Stilpnus from Costa Rica (GRB: pers. observ.) are extensively pale; at least two undescribed species of Nipponaetes in the AEI are almost entirely creamy coloured; several undescribed species of the Chirotica group in the BMNH have pale heads; and $N$. haeussleri has large, pale, triangular marks on the malar space. The pale mesopleuron reduces the visibility of the sternaulus of $Z$. hansoni but it is present and complete, best viewed from below. The number of shared character states between Zurquilla and Nipponaetes, the presence of at least one cryptine apomorphy (the long, strong sternaulus) and the absence of any convincing tryphonine apomorphies leads us to synonymise Zurquilla under Nipponaetes. The genus now comprises the following five species, with distributions taken from Gupta (1987) and Yu \& Horstmann (1997).

\author{
Nipponaetes Uchida, 1933 \\ Potia Seyrig, 1952 \\ Thalops Townes, 1958 \\ Zurquilla Gauld, 1997, syn. nov. \\ fessus (Townes, 1958): Micronesia \\ haeussleri (Uchida, 1933): India, China, Philippines, Korea, \\ Japan, Ryukyu archipelago, Thailand \\ hansoni (Gauld, 1997): Costa Rica \\ inelegans (Seyrig, 1952): Madagascar \\ striatus Momoi, 1970: Ryukyu archipelago
}

In addition, undescribed species are represented by specimens in the AEI from Malaysia and the Philippines and Gauld (1984) records an undescribed species from Australia. Although Nipponaetes has previously been considered to be a genus of the Old World tropics (Tow- 

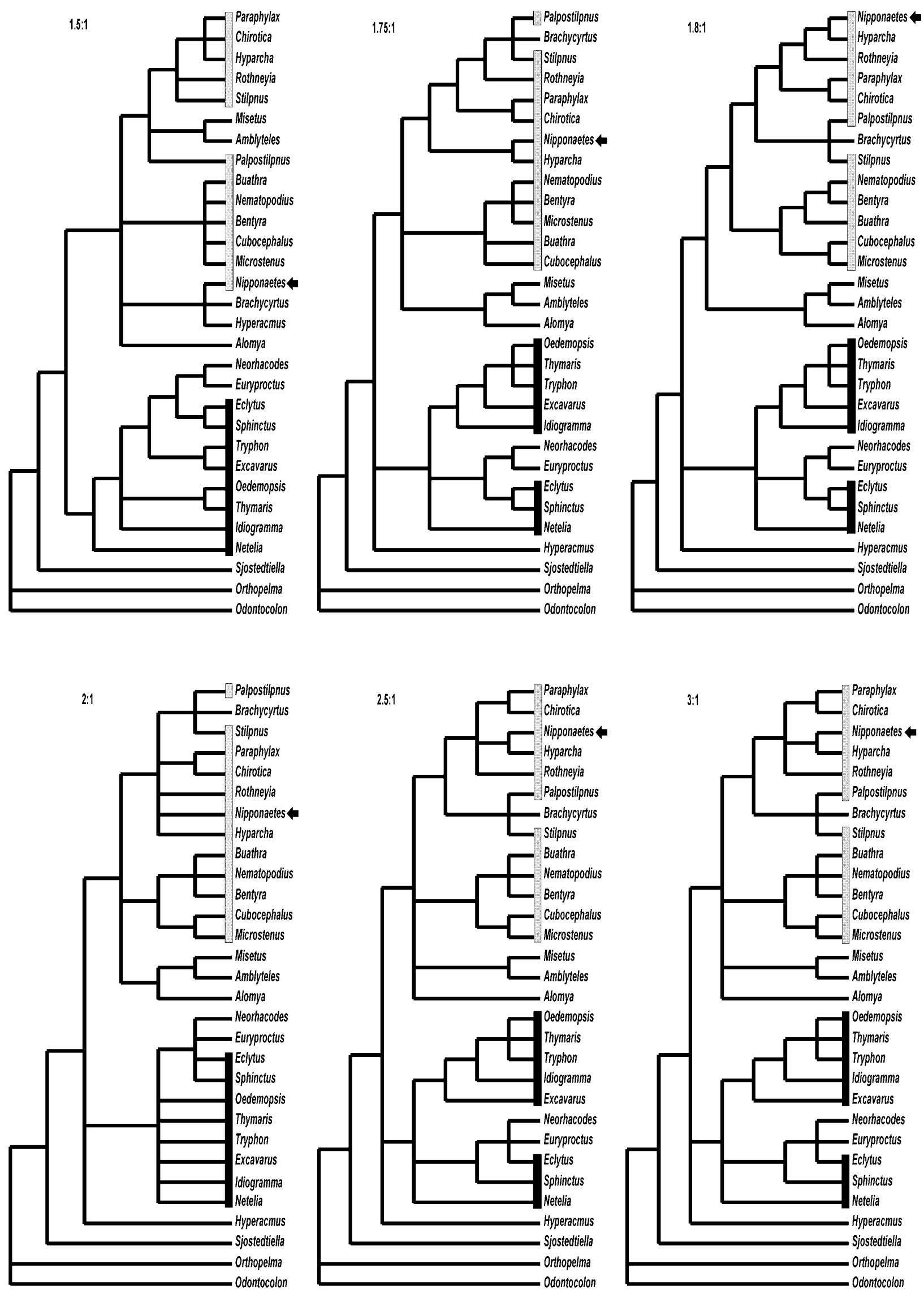

Fig. 1. Trees from the POY analysis with relative gap: substitution costs $1.5,1.75,1.8,2,2.5$ and 3 . Taxa belonging to the Cryptinae are indicated by black bars and taxa belonging to the Tryphoninae are indicated by grey bars. The position of Nipponaetes is indicated with an arrow in each tree. 
nes, 1970; Gupta, 1987), synonymisation of Zurquilla results in a pan-tropical distribution.

Nipponaetes can be distinguished from all other ichneumonid genera by the following combination of features:

1. complete sternaulus, ending above posterior ventral corner of the mesopleuron;

2. first tergite and sternite fused, spiracle far behind mid-length of segment;

3. complete or narrowly interrupted posterior transverse carina on the mesosternum;

4. single bulla in fore wing vein $2 m$-cu;

5. upper mandibular tooth much longer then lower tooth;

6. notauli long, deeply impressed and posteriorly convergent.

\section{Biology}

The only host information previously presented for Nipponaetes is the assertion, without any supporting information, that it is a parasitoid of Cydia molesta (Busck, 1916) (Lepidoptera: Tortricidae) in Japan (Uchida, 1933). However, there is doubt associated with this record as neither the holotype nor paratype was accompanied by host data in Uchida's original description, unlike other species in the paper. A species of Ichneumoninae subsequently described by Uchida and sharing the same specific name, Phaeogenes haeussleri Uchida, 1935, is a parasitoid of tortricid fruit moths (Garman, 1940) and clearly there is some potential for confusion. We found three previously unidentified specimens of $N$. haeussleri in the "Chiroticina" drawers of the Cryptinae collections in the NHM. These specimens, all females, are labelled as "ex spider eggs", from "India: Orissa, Cuttack 1981" and presented by the Commonwealth Institute of Entomology. The form of the ovipositor, tapered to a point, lacking nodus and obvious teeth, compares well with other cryptine genera with known spider egg sac associations (Fitton et al., 1987; Schwarz \& Shaw, 2000).

ACKNOWLEDGEMENTS. We thank O.P. Khoo for running a Malaise trap in Malaysia; M. Barclay, H. Basibuyuk, S. Belokobylski, I. Gauld, G. Goergen, M. Kuhlman, M. Shaw and S.-H. Yen for the donation of specimens; and D. Wahl for hospitality to the senior author whilst visiting the AEI. Thanks also to M. Shaw, D. Vane-Wright and J. Noyes for their comments on the manuscript. This project was funded by an E. and G. Ehrnroothin Foundation grant to N. Laurenne.

\section{REFERENCES}

Belshaw R., Fitton M.G., Herniou E., Gimeno C. \& Quicke D.L.J. 1998: A phylogenetic reconstruction of the Ichneumonoidea (Hymenoptera) based on the D2 variable region of $28 \mathrm{~S}$ ribosomal RNA. Syst. Entomol. 23: 109-123.
Belshaw R. \& Quicke D.L.J. 2002: Robustness of ancestral state estimates: evolution of life history strategy in ichneumonoid parasitoids. Syst. Biol. 51: 450-477.

FitTon M.G., Shaw M.R. \& Austin A.D. 1987: The Hymenoptera associated with spiders in Europe. Zool. J. Linn. Soc. 90: 65-93.

Garman P. 1940 Oriental fruit moth parasites. Connect. Ag. Exp. St., New Haven. Circ. 140: 29-47.

GAULD I.D. 1984: An Introduction to the Ichneumonidae of Australia. With a Contribution on Metopiinae by M.G. Fitton. British Museum (Natural History), London, 413 pp.

GaUld I.D. 1997: Ichneumonidae of Costa Rica, 2. Mem. Am. Entomol. Inst. 57: 1-485.

GupTA V.K. 1987: The Ichneumonidae of the Indo-Australian area (Hymenoptera). Mem. Am. Entomol. Inst. 41: 1-1210.

GUPTA V.K. 1988: Relationships of the genera of the tryphonine tribe Oedemopsini and a revision of Acaenitellus Morley (Hymenoptera: Ichneumonidae: Tryphoninae). In Gupta V.K. (ed.): Advances in Parasitic Hymenoptera Research. E.J. Brill, Leiden, New York, pp. 243-258.

Laurenne N.M., Broad G.R. \& Quicke D.L.J. 2002: Preliminary molecular phylogenetic analysis of Cryptinae and related taxa based on 28S D2+D3 rDNA analysed using POY. In Melika G. \& Thuroczy C. (eds): Parasitic Hymenoptera: Evolution, Systematics, Biodiversity and Biological Control. Agroinform, Budapest, pp. 229-233.

Mомо S. 1970: Ichneumonidae (Hymenoptera) of the Ryukyu Archipelago. Pacific Ins. 12: 327-399.

Quicke D.L.J., Fitton M., Notton D., Broad G.R. \& Dolphin K. 2000: Phylogeny of the Ichneumonidae (Hymenoptera): a simultaneous molecular and morphological analysis. In Austin A.D. \& Dowton M. (eds): Hymenoptera: Evolution, Biodiversity and Biological Control. CSIRO Publishing, Canberra, pp. $74-83$.

Schwarz M. \& Shaw M.R. 2000: Western Palaearctic Cryptinae (Hymenoptera: Ichneumonidae) in the National Museums of Scotland, with nomenclatural changes, taxonomic notes, rearing records and special reference to the British check list. Part 3. Tribe Phygadeuontini, subtribes Chiroticina, Acrolytina, Hemitelina and Gelina (excluding Gelis), with descriptions of new species. Entomol. Gaz. 51: 147-186.

Seyrig A. 1952: Les Ichneumonides de Madagascar 4. Ichneumonidae Cryptinae. Mem. Acad. Malgache 39: 1-213.

Townes H. 1958: Hymenoptera: Ichneumonidae, Stephanidae and Evaniidae. Ins. Micronesia 19: 35-87.

Townes H. 1970: The genera of Ichneumonidae, Part 2. Mem. Am. Entomol. Inst. 12: 1-537.

UchiDA T. 1933: Über die Schmarotzerhymenopteren von Grapholitha molesta Busck in Japan. Ins. Matsumurana 7: 153-164.

WheEler W.C. \& Gladstein D. 2000: POY: The Optimization of Alignment Characters. American Museum of Natural History, New York. Program and documentation available at ftp://ftp.amnh.org/pub/molecular/poy/.

Yu D.S. \& Horstmann K. 1997: A catalogue of world Ichneumonidae (Hymenoptera). Mem. Am. Entomol. Inst. 58: $1-1558$.

Received January 26, 2004; revised May 5, 2004; accepted May 5, 2004 